Agro-Science Journal of Tropical Agriculture, Food, Environment and Extension Volume 17 Number 3 (September 2018) pp. 19-26

ISSN 1119-7455

\title{
EFFECT OF PIG MANURE ON GROWTH AND PRODUCTIVITY OF TWENTY ACCESSIONS OF Moringa oleifera IN NIGERIA
}

\author{
${ }^{1}$ Stevens C.G., ${ }^{2}$ Ugese F.D. and ${ }^{* 1}$ Baiyeri K.P. \\ ${ }^{1}$ Department of Crop Science, University of Nigeria, Nsukka, Nigeria \\ ${ }^{2}$ Department of Crop Production, University of Agriculture, PMB 2373 Makurdi, Nigeria \\ *Corresponding author's email: paul.baiyeri@unn.edu.ng
}

\begin{abstract}
An experiment to determine the effect of pig waste on the survival, growth and productivity of 20 accessions of Moringa oleifera from the various agroecologies in Nigeria was conducted from August 2011 to November 2012. The experiment was a factorial combination of 3 rates of pig waste $-0,10$ and 20 t/ha - and 20 accessions of Moringa oleifera. Analysis of variance results indicated a general decline in survival percentage of the accessions with time with the Kolo accession showing the highest survival percentage of 84.4\% 15 months after transplanting, while Baruten recorded the lowest survival rate (37.8\%). There were significant variations across accessions in all the morphological and pod and seed parameters evaluated. The accession from Kolo showed the tallest plants and the widest stem girth while Ugya produced more leaves at the last measurement. Kolo, Ugya, Idere and Awo - Garaji had comparatively higher dry weights than other accessions. There was a linear response to pig waste application although the 0 and 10 t/ha rates were statistically the same. Variation in the pattern of response of reproductive parameters to organic manure was noticed with Baruten and Zaria not producing viable pods at manure rate of 10 t/ha while Idere and Maiduguri failed to bear pods at rates of 20 t/ha. Accessional differences in survival and growth can be exploited for selection and breeding purposes while organic manure can be utilized to improve growth and yield of the species.
\end{abstract}

Key words: accessions, Moringa oleifera, pig waste, growth, productivity

\section{INTRODUCTION}

Moringa oleifera belongs to the family Moringaceae which has 14 species. Of these species, the most common and widely cultivated is Moringa oleifera (Makkar and Becker, 1997; Marcu, 2006). It is a drought tolerant plant whose tuberous tap root system is an in-built mechanism against water stress. Moringa is believed to be native to India but now found in semi-arid, tropical and sub-tropical climates (Moyo et al., 2011). Moringa oleifera is commonly called the drumstick tree for its pods that are used in drumming or the horse radish tree due to the flavour of its roots (Palada and Chang, 2003). It thrives in a wide variety of soils and climate, but prefers sandy-loam soil and areas with temperature of 25 to $40{ }^{\circ} \mathrm{C}$, an annual rainfall of at least $500 \mathrm{~mm}$, and elevation of 600-1000 m above sea level. (Rajakrishnamoorthy et al., 1994). The plant is considered one of the most useful species of the world, being invaluable as human food, browse plant, medicine and water purifier (Palada and Chang, 2003). In Nigeria, Moringa has a longstanding use as live fence, ornamental plant, yam stakes and snake repellent (Stevens, 2014).

Yield variation is dependent on such factors as accession, season, fertilization and irrigation regime. And although the plant is an efficient nutrient miner owing to its deep and extensive root system, growth and yields can be optimized by application of organic or inorganic fertilizers (Palada and Chang, 2003). Generally produce quantity and quality is enhanced with application of fertilizers (Ani and Baiyeri, 2008). Ramachandran et al. (1980) achieved higher yields with organic fertilizer than growing Moringa without fertilizer. A positive response was obtained when manures (poultry/cow dung), bio-fertilizers and NPK at different levels were used in the management of Moringa (Beulah, 2001). Adebayo et al. (2011) in their study observed increased vegetative growth and dry matter yield of $M$. oleifera with organic amendment

For certain reasons, organic manure is preferred to inorganic fertilizers. Apart from adding nutrients 
to the soil (Ndukwe et al., 2009), it also improves soil properties (Thompson and Troel, 1978) and acts as a liming material by reducing soil acidity (Olatunji et al., 2012). The problem of nonavailability of inorganic fertilizers in their right quantities has become acute since the federal government disengaged from fertilizer importation and distribution in 1997. Consequently, most farmers now use organic manure (Ojanuga, 2006). In the study area, Nsukka, in south-eastern Nigeria, pig waste is readily available and cheaper than poultry manure and other organic fertilizers. This is most likely the case in other parts of Nigeria where pig rearing is common. In okra, application of pig waste has been shown to increase the yield of the crop by more than $50 \%$ (Olatunji and Oboh, 2012). Since report of this manure in moringa culture in Nigeria is very scanty, we decided to test the response of the species to pig waste.

\section{MATERIALS AND METHODS}

Ripe pods of Moringa oleifera were collected from the following locations across Nigeria in 2011: Awo-Anekpa, Baruten, Mayo-Belwa, Dooshima, Maiduguri, Awo-Garaji, Giri, Idere, Iri, Ityomu, Kano, Kolo, Kontagora, Kuje, Nsukka, Rini, Ugya, Yola, Zaria and Zuru. Seeds were extracted from the pods and grown in the nursery. Seedlings were transplanted from the nursery after 1 month at an intra-row distance of $0.5 \mathrm{~m}$ and inter-row distance of $1.0 \mathrm{~m}$ on a single row plot of 5 plants. Organic manure (pig waste) was applied to the seedlings at one month after transplanting at the rates of 0,10 and $20 \mathrm{t} / \mathrm{ha}$. The experiment was $3 \times 20$ factorial in randomized complete block design and replicated three times. Treatments were pig waste ( 3 levels 0, $1020 \mathrm{t} / \mathrm{ha}$ ) and 20 accessions of Moringa leifera.

The experiment was conducted between August 2011 and Nov 2012 at the Research Farm of the Department of Crop Science, University of Nigeria, Nsukka. Data were collected on survival, plant height, plant girth and number of leaves per plant at 6, 9, 12 and 18 months after transplanting (MAT). Fully expanded leaves were counted and recorded as number of leaves per plant. Plant height was measured $2 \mathrm{~cm}$ from the ground with a meter rule while plant girth was taken with a $15 \mathrm{~cm}$ vernier calipers and a meter rule on individual plants in a plot. Fresh and dry weight yields were determined after pruning at 18 MAT using a digital weighing balance while the leaves and stems were dried in the oven at $60^{\circ} \mathrm{C}$ to constant weights. Pod and seed characters were also determined.

Data collected were subjected to analysis of variance according to the procedure for a two factorial experiment in RCBD. Separation of treatment means for statistical significance was done using the least significant difference as outlined by Obi (2002).

\section{RESULTS}

Properties of soil of the experimental site and pig waste are presented in Table 1. Pig manure had higher values of $\mathrm{pH}$, organic matter and nitrogen when compared to the soil values. The main effect of the factors on morphological growth parameters measured showed significant variations $(\mathrm{p}<0.05)$ across accessions (Table 2). There was a clear pattern of decreasing survival percentage for most of the accessions, from 6 to 15 MAT.

Thus, at 6 MAT, $75 \%$ of the accessions recorded up to $70 \%$ survival. This decreased progressively to only $30 \%$ of accessions recording up to $70 \%$ survival at the final stage of assessment (15 MAT), Zaria maintained a steady survival percentage of 84.40 for one year which dropped to $68.90 \%$ at 15 MAT. Baruten had the lowest survival percentage throughout the period of the experiment as shown while Kolo had the highest value $(80 \%)$ over a period of 15 MAT. In contract to the decreasing survival percentage, plant height and other morphological attributes increased from 6 to 15 MAT (Table 2). Although Kano had the lowest plant height at the beginning (6 MAT) and at the end (15 MAT), Kolo which ended up the tallest was not the highest from the beginning. It also recorded larger girth than other accessions while Ugya had more leaves 15 MAT. Interestingly, Kolo recorded significantly higher number of leaves per plant than other accessions at 12 MAT when there was a general drop in leaf number. Effect of interaction of the factors on growth characters (Table 3) showed that the Yola accession grew taller than others when 0 or $10 \mathrm{t} / \mathrm{ha}$ application of manure was made. However, the highest dose of application (20 t/ha) favoured Ugya. This later accession also exceeded others in stem girth and number of leaves at this manure rate. When no manure was applied, Kolo and Ugya had larger girths. Control plots of Kolo and Nsukka accessions had more leaves than others. For all morphological parts examined, mean response to manure rate was in the order $20 \mathrm{t} / \mathrm{ha}>10 \mathrm{t} / \mathrm{ha}>0$ t/ha. Similar pattern of response was observed for leaf and stem dry weights (Table 4). In summary, Kolo and Ugya had highest leaf dry weight. Kolo, followed by Idere and Awo - Garaji also recorded higher stem dry weights than other accessions.

The main effect of accession on pod and seed characters of the $20 \mathrm{M}$. oleifera accessions across Nigeria is presented in Table 5. The Giri, Idere and Kolo accessions produced more than four pods per plant. Kano accession on the other hand did not produce any pods. Pod circumference varied from a high of $5.80 \mathrm{~cm}$ (Idere) to a low of $0.48 \mathrm{~cm}$ (Zaria). Pods produced by Awo - Garaji and Idere were the longest, being longer than $20 \mathrm{~cm}$; while pods from Baruten accession were the shortest $(3.19 \mathrm{~cm})$. Pods produced by seeds sourced from Maiduguri were the heaviest while those of Kano were the lightest. 
Table 1: Soil properties of the experimental site and pig waste

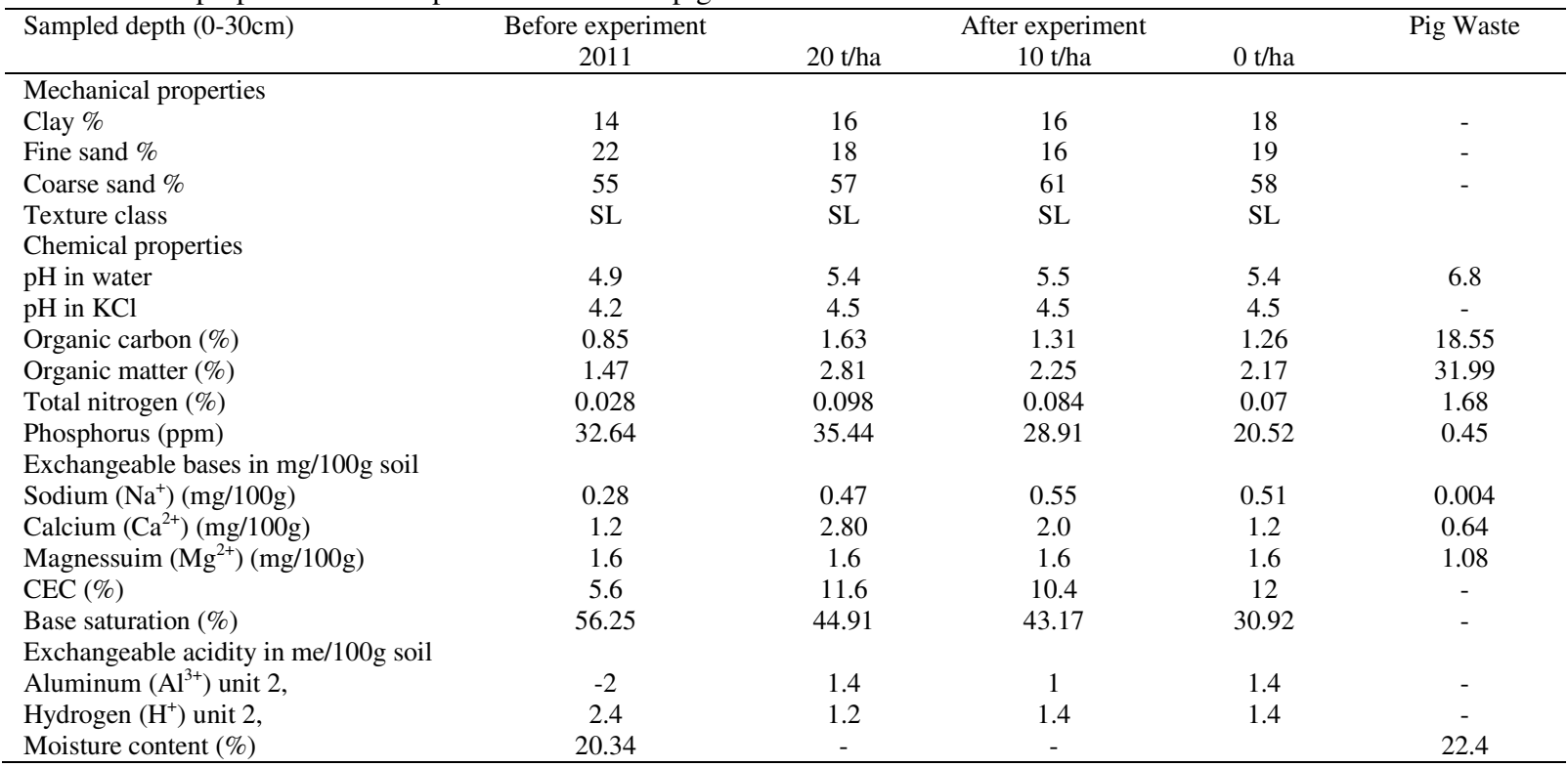

Idere, Giri and Yola accessions produced more than eight seeds per pod. In contrast, the Kano provenance only managed to produce one seed per pod.

The heaviest seeds came from Maiduguri, Awo - Garaji and Giri while the lighter ones were from Baruten and Zaria. It was remarkable that at $0 \mathrm{t} / \mathrm{ha}$ manure rate, Yola accession produced the highest number of pods; Awo - Anekpa, Maiduguri, Kontagora and Zuru did not produce any viable pods, that is pods with seeds. At 10t/ha, Baruten and Zaria did not produce viable pods but Irri and Awo - Garaji produced highest pod numbers. At the highest application of manure (20 t/ha), Idere and Maiduguri did not produce pods (Data not shown). All the accessions that did not produce viable pods at those manure rates indicated above did not produce seeds. Correlation coefficients between evaluated characters showed a number of significant positive relationships (Table 7). Thus, most of the growth traits had significant positive relationships with each other and with the other traits. The only notable exception was number of leaves which had positive correlations with all other traits but was significantly so only with stem girth. The latter's relationship with pod weight; seed number and plant height was positive but nonsignificant.

\section{DISCUSSION}

Laboratory analysis shows that compared to soil values, pig manure is particularly high in $\mathrm{pH}$, organic matter and nitrogen. Although the textural class (sandy loam) fits the requirements for Moringa growth (Price 2007), the $\mathrm{pH}$ of 4.9 is a little out of range with the neutral to slightly acidic soil $\mathrm{pH}$ of 5.0-7.0 prescribed for the species (Palada and Changi, 2003). Nsukka soils are noted for their acidity (Baiyeri and Tenkouano, 2007), which imposes limitation on amount of nutrients available to the plant (Baiyeri and Mbah, 2006). In the context of this, application of organic manure becomes desirable. Poultry manure in particular, has been linked with reduction of soil acidity apart from soil nutrient enrichment (Olatunji and Oboh, 2012; Sunassee, 2001). The reduction in exchangeable acidity and improvement in the soil $\mathrm{pH}$ from 4.9 to 5.5 as well as increased nutrient status of the site (especially the plots that received $20 \mathrm{t} / \mathrm{ha}$ ) in organic matter, total nitrogen, phosphorus, calcium and base saturation as indicated in 2013 soil analyses result may be attributed to the application of pig waste. This indicates a mode of action similar to that of poultry manure and highlights the importance of pig waste in soil improvement. Generally, organic materials are known to modify soil properties (Thompson and Troeh, 1978) and boost the soil nutrient content (Dauda et al. 2005; Ndukwe et al. 2009). The decreasing survival percentage with increasing number of months contradicts the age- long belief that Moringa is a 'never die' tree, thriving in areas of extreme climatic conditions and destitute soils. This suggests that the species is still susceptible to the vicissitudes of environmental factors as is common with other species. In an international provenance trial of the Neem tree (Azadirachta indica) involving 23 provenances, Lamichhane and Thapa (2011) observed a survival rate ranging from $33-92 \%$ in the $5^{\text {th }}$ year of tree establishment. In this report, the highest survival rate after 15 months of transplanting was $80 \%$. With few exceptions, evaluated traits (growth and yield parameters) showed linear response to manure rates. This confirms the well acknowledged role of fertilization in enhancing the performance of the species (Price, 2000; Ramachandra et al., 1980). 
Table 2: Main effect of accession on survival and morphological growth parameters of Moringa oleifera at 6, 9, 12, and 15 months after transplanting (MAT)

\begin{tabular}{|c|c|c|c|c|c|c|c|c|c|c|c|c|c|c|c|c|}
\hline \multirow[b]{2}{*}{ Accession } & \multicolumn{4}{|c|}{ 6 MAT } & \multicolumn{4}{|c|}{ 9 MAT } & \multicolumn{4}{|c|}{$12 \mathrm{MAT}$} & \multicolumn{4}{|c|}{15 MAT } \\
\hline & SURV & PHT & NOL & PGT & SURV & PHT & NOL & PGT & SURV & PHT & NOL & PGT & SURV & PHT & NOL & PGT \\
\hline Awo-Anekpa & 80.00 & 75.50 & 3.48 & 11.47 & 80.00 & 123.20 & 16.25 & 20.99 & 80.00 & 139.80 & 1.59 & 23.56 & 73.30 & 148.80 & 1.40 & 25.29 \\
\hline Baruten & 44.40 & 56.60 & 1.84 & 9.01 & 40.00 & 106.70 & 12.01 & 15.68 & 40.00 & 137.50 & 2.28 & 19.31 & 37.80 & 146.80 & 4.80 & 21.76 \\
\hline Mayo-Belwa & 77.80 & 69.20 & 3.81 & 10.76 & 75.60 & 121.60 & 15.93 & 17.05 & 71.10 & 146.70 & 2.60 & 19.82 & 68.90 & 158.30 & 6.53 & 22.43 \\
\hline Dooshima & 86.70 & 81.60 & 2.32 & 11.59 & 86.70 & 125.60 & 18.42 & 19.33 & 80.00 & 140.40 & 3.60 & 22.89 & 75.60 & 156.30 & 5.52 & 24.34 \\
\hline Maiduguri & 64.40 & 67.90 & 1.29 & 10.50 & 62.20 & 109.00 & 16.92 & 17.52 & 62.20 & 123.00 & 1.86 & 20.54 & 53.30 & 147.10 & 7.77 & 23.00 \\
\hline Awo-Garaji & 84.40 & 94.00 & 2.96 & 13.40 & 80.00 & 135.90 & 23.74 & 22.45 & 75.60 & 153.00 & 3.83 & 27.32 & 68.90 & 171.50 & 8.42 & 30.61 \\
\hline Giri & 91.10 & 74.90 & 2.21 & 12.00 & 84.40 & 113.30 & 18.57 & 18.64 & 84.40 & 131.30 & 2.94 & 23.50 & 77.80 & 153.90 & 8.31 & 27.25 \\
\hline Idere & 88.90 & 86.10 & 1.87 & 13.07 & 88.90 & 139.90 & 27.54 & 22.96 & 82.20 & 150.60 & 2.97 & 26.75 & 77.80 & 163.10 & 8.50 & 28.65 \\
\hline Iri & 71.10 & 64.40 & 3.08 & 9.99 & 68.90 & 109.30 & 22.62 & 16.42 & 66.70 & 120.90 & 4.10 & 19.20 & 51.10 & 149.10 & 6.67 & 23.67 \\
\hline Ityomu & 77.80 & 70.10 & 2.67 & 10.99 & 71.10 & 107.40 & 18.71 & 17.53 & 68.90 & 117.40 & 3.38 & 19.13 & 68.90 & 123.70 & 5.03 & 20.24 \\
\hline Kano & 55.60 & 38.90 & 2.91 & 6.92 & 48.90 & 79.30 & 13.04 & 13.12 & 48.90 & 90.50 & 1.06 & 15.00 & 46.70 & 100.90 & 5.93 & 16.64 \\
\hline Kolo & 86.70 & 88.10 & 4.32 & 13.42 & 80.00 & 141.80 & 27.42 & 24.90 & 80.00 & 167.00 & 7.30 & 30.71 & 80.00 & 187.20 & 14.99 & 33.76 \\
\hline Kontagora & 88.90 & 63.80 & 2.88 & 9.47 & 86.70 & 96.80 & 15.78 & 15.05 & 82.20 & 109.70 & 2.49 & 17.19 & 66.70 & 119.20 & 7.14 & 19.11 \\
\hline Kuje & 53.30 & 63.10 & 3.32 & 10.79 & 51.10 & 103.80 & 17.98 & 18.04 & 48.90 & 114.30 & 1.59 & 19.69 & 46.70 & 128.40 & 4.37 & 22.28 \\
\hline Nsukka & 82.20 & 88.60 & 4.71 & 13.14 & 82.20 & 128.10 & 19.07 & 19.66 & 77.80 & 143.90 & 2.48 & 23.52 & 71.10 & 160.60 & 7.04 & 27.41 \\
\hline Rini & 71.10 & 71.70 & 2.82 & 10.36 & 68.90 & 111.30 & 20.69 & 17.20 & 66.70 & 119.50 & 2.78 & 19.30 & 53.30 & 136.20 & 8.89 & 21.55 \\
\hline Ugya & 73.30 & 71.20 & 3.86 & 11.71 & 71.10 & 108.10 & 21.06 & 20.44 & 68.90 & 127.00 & 4.53 & 26.17 & 62.20 & 160.20 & 23.62 & 30.28 \\
\hline Yola & 64.40 & 92.50 & 3.65 & 12.37 & 62.20 & 137.90 & 21.49 & 20.40 & 60.00 & 162.60 & 4.50 & 23.86 & 57.80 & 180.70 & 8.39 & 26.79 \\
\hline Zaria & 84.40 & 61.90 & 4.06 & 10.26 & 84.40 & 93.60 & 13.57 & 14.14 & 84.40 & 101.50 & 1.61 & 16.32 & 68.90 & 123.60 & 2.03 & 19.82 \\
\hline Zuru & 77.80 & 67.30 & 2.99 & 10.25 & 71.10 & 114.20 & 15.61 & 16.18 & 64.40 & 131.60 & 2.37 & 19.38 & 60.00 & 144.00 & 5.49 & 21.50 \\
\hline $\operatorname{LSD}_{(0.05)}$ & 21.10 & 20.97 & 1.60 & 2.60 & 21.46 & 29.83 & 7.74 & 4.91 & 22.04 & 34.51 & 3.31 & 6.20 & 22.52 & 40.23 & 9.48 & 6.85 \\
\hline
\end{tabular}

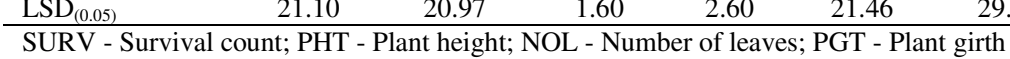


Stevens C.G., Ugese F.D. and Baiyeri K.P.

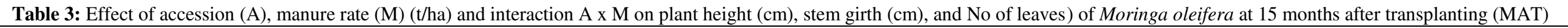

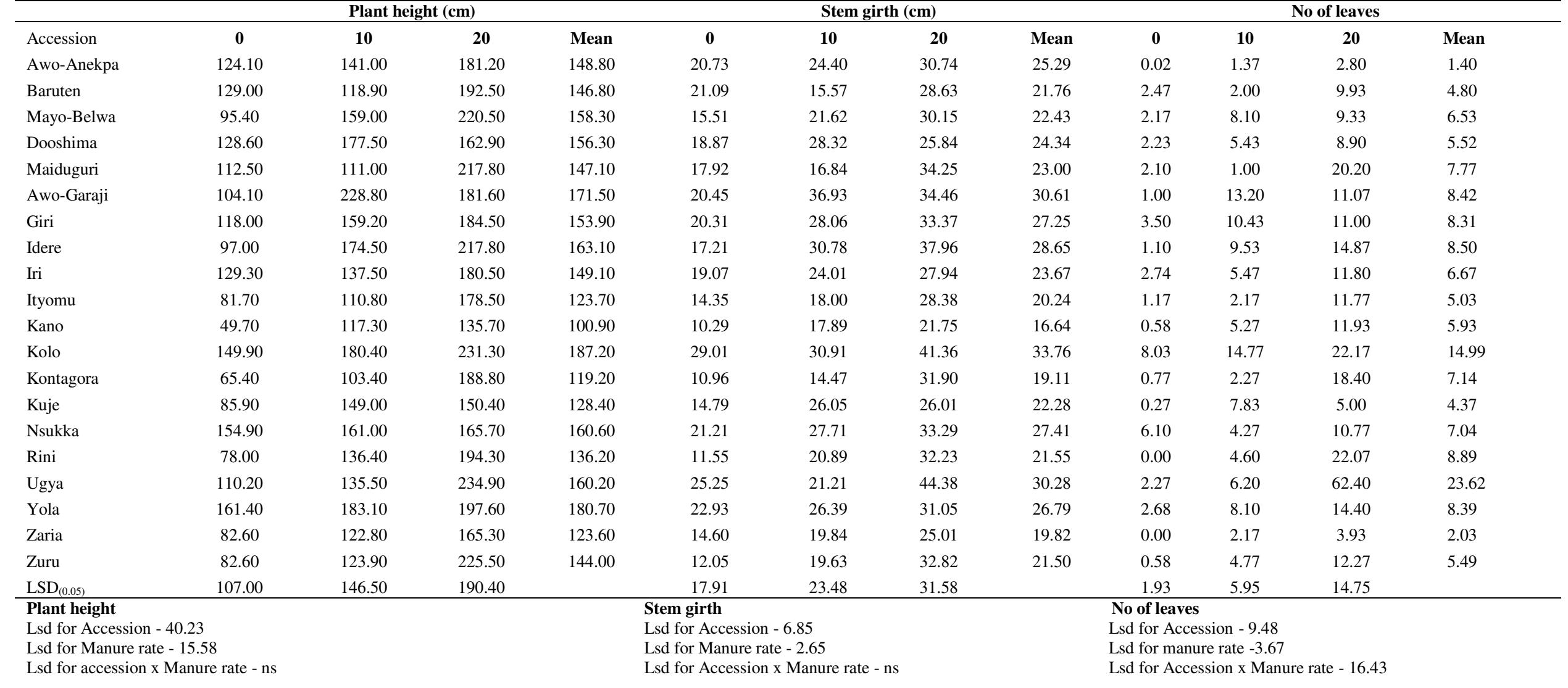


Table 4: Effect of accession (A), manure rate (M) (t/ha) and interaction A x M on leaf and stem dry weight (g) of Moringa oleifera at 15 months after transplanting

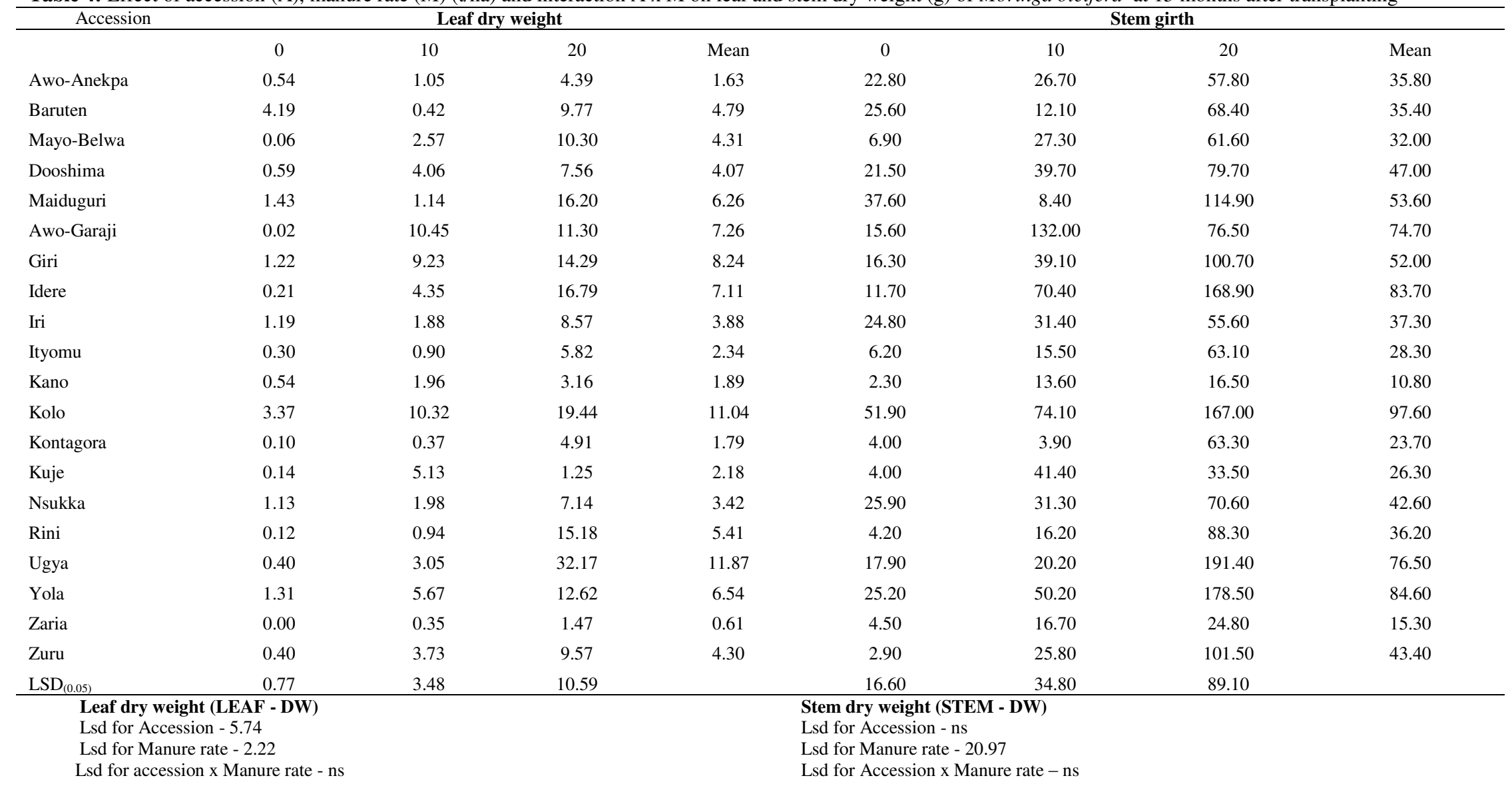


Table 5: Main effect of accession on the pod and seed parameters of Moringa oleifera

\begin{tabular}{|c|c|c|c|c|c|c|}
\hline Accession & Pods/plant & $\begin{array}{l}\text { Pod circumference } \\
(\mathrm{cm})\end{array}$ & $\begin{array}{l}\text { Pod length } \\
(\mathrm{cm})\end{array}$ & $\begin{array}{l}\text { Pod weight } \\
\text { (g) }\end{array}$ & Seed No/pod & $\begin{array}{l}\text { Seed weight } \\
(\mathrm{cm})\end{array}$ \\
\hline Awo-Anekpa & 2.44 & 0.76 & 6.39 & 0.90 & 2.56 & 0.42 \\
\hline Baruten & 2.44 & 0.26 & 3.19 & 0.27 & 1.28 & 0.18 \\
\hline Mayo-Belwa & 2.33 & 1.51 & 8.62 & 1.62 & 3.06 & 0.79 \\
\hline Dooshima & 3.33 & 2.95 & 16.80 & 2.51 & 3.72 & 1.20 \\
\hline Maiduguri & 2.78 & 3.59 & 20.45 & 4.22 & 7.50 & 1.96 \\
\hline Awo-Garaji & 3.78 & 3.74 & 22.88 & 3.73 & 7.69 & 1.83 \\
\hline Giri & 4.44 & 3.43 & 18.37 & 3.13 & 8.61 & 1.81 \\
\hline Idere & 4.22 & 3.80 & 21.36 & 3.73 & 9.06 & 1.94 \\
\hline Iri & 3.89 & 3.57 & 19.61 & 2.74 & 6.74 & 1.55 \\
\hline Ityomu & 3.00 & 1.82 & 10.15 & 1.32 & 2.89 & 0.74 \\
\hline Kano & - & - & - & - & - & - \\
\hline Kolo & 4.11 & 3.56 & 18.55 & 3.31 & 5.25 & 1.37 \\
\hline Kontagora & 2.33 & 1.71 & 8.50 & 2.02 & 3.33 & 1.01 \\
\hline Kuje & 2.76 & 2.56 & 12.93 & 1.67 & 3.96 & 1.21 \\
\hline Nsukka & 2.22 & 0.84 & 5.48 & 0.54 & 2.11 & 0.43 \\
\hline Rini & 2.67 & 2.90 & 11.94 & 2.68 & 6.22 & 1.52 \\
\hline Ugya & 3.11 & 2.11 & 9.00 & 1.16 & 1.67 & 0.73 \\
\hline Yola & 3.11 & 3.72 & 17.16 & 3.67 & 8.22 & 1.70 \\
\hline Zaria & 1.89 & 0.48 & 2.50 & 0.34 & 1.00 & 0.22 \\
\hline Zuru & 2.56 & 1.52 & 7.17 & 1.27 & 2.83 & 0.71 \\
\hline $\operatorname{LSD}_{(0.05)}$ & 1.25 & 2.07 & 11.46 & 2.07 & 4.75 & 0.37 \\
\hline
\end{tabular}

Table 6: Effect of pig waste on pod and seed characters of twenty accessions of $M$. oleifera at Nsukka, Nigeria

\begin{tabular}{lccccc}
\hline $\begin{array}{l}\text { Manure } \\
\text { rate } \\
(\mathrm{t} / \mathrm{ha})\end{array}$ & $\begin{array}{c}\text { Pod } \\
\text { weight } \\
(\mathrm{g})\end{array}$ & $\begin{array}{c}\text { Pod } \\
\text { length } \\
(\mathrm{cm})\end{array}$ & $\begin{array}{c}\text { Pod } \\
\text { circum- } \\
\text { ference } \\
(\mathrm{cm})\end{array}$ & $\begin{array}{c}\text { Seeds } \\
\text { /pod }\end{array}$ & $\begin{array}{c}\text { Seed } \\
\text { weight } \\
(\mathrm{g})\end{array}$ \\
\hline 0 & 1.4 & 10.6 & 1.6 & 4.0 & 0.8 \\
10 & 1.7 & 11.6 & 2.1 & 4.0 & 0.9 \\
20 & 3.1 & 14.0 & 3.0 & 5.1 & 1.6 \\
\hline $\mathrm{LSD}_{(0.05)}$ & 0.80 & $\mathrm{NS}$ & 0.80 & $\mathrm{NS}$ & 0.40
\end{tabular}

Adebayo et al. (2011) found that organic amendment increased both the vegetative and dry matter yield of $M$. oleifera. Similarly, higher leaf production in Moringa was attained with higher fertilizer rate (Abdullahi et al., 2013). Increased pod/seed production with increase in manure rate confirm the report of Olatunji and Oboh (2012) in okra (Abelmoscus esculentum) where pod yield was increased by $52 \%$ as a result of the application of pig waste. This clearly shows that although Moringa may thrive in destitute soils, it does better with the application of organic manure.The accession from Kolo which maintained high leaf number throughout the year is a possible candidate for fodder. Current research efforts are geared towards identifying plants that can provide fodder all year round (Nouman et al., 2013). As stated earlier, M. oleifera is known to do reasonably well even in marginal soils. Results obtained in this study point to accessional differences in this regard. For instance, with no manure application, Yola produced very heavy pods while accessions like Awo - Anekpa, Maiduguri, Kontagora and Zuru did not produce either viable pods or seeds at this rate. Still some did not produce viable pods or seeds at 10 or $20 \mathrm{t} / \mathrm{ha}$. It is possible that at $0 \mathrm{t} / \mathrm{ha}$ of pig waste, soil fertility status was too low to support pod/seed production of some accessions. Failure of some accessions to produce pods/seeds at higher manure rates could indicate their lack of tolerance to such high levels of fertility for reproductive performance. It would have been reasonable to suggest that at higher soil nutrient levels, poor reproductive performance was compensated for by increased vegetative growth. However, this cannot be categorically stated as correlation analysis has failed to support this opinion. The relationship between vegetative and reproductive parameters was positive and in most cases, significantly so. This pattern of response to manure application may need further investigation for more definitive conclusions to be reached.

However, the inability of the Kano accession (Sudan savannah agro-ecological zone) to produce any pod at all may be attributed to genetic defect or poor adaptation to Nsukka environment. What is immediately evident is that such accessional variations may present opportunities for selection for breeding towards particular requirements. Alternatively, seeds from such accessions may be selected for planting based on soil nutrient status or the grower's management capacity. The high level of significant positive relationships among examined traits is heartwarming. The implication is that agronomic interventions seeking to increase vegetative yield would generally improve pod and seed production. Conversely, those interventions seeking to improve reproductive performance will also most likely enhance vegetative yield. Thus there will be no separate interventions for improving either vegetative growth or reproductive performance. 
Table 7: Correlation coefficients between vegetative, dry weight and reproductive characters of $M$. oleifera at Nsukka, Nigeria

\begin{tabular}{|c|c|c|c|c|c|c|c|c|c|c|}
\hline & $\begin{array}{c}\text { Stem } \\
\text { dry } \\
\text { weight }\end{array}$ & $\begin{array}{c}\text { Leaf } \\
\text { dry } \\
\text { weight }\end{array}$ & $\begin{array}{l}\text { No of } \\
\text { leaves }\end{array}$ & $\begin{array}{l}\text { Stem } \\
\text { girth }\end{array}$ & $\begin{array}{c}\text { Plant } \\
\text { height }\end{array}$ & $\begin{array}{c}\text { Seed } \\
\text { weight }\end{array}$ & $\begin{array}{c}\text { Seed } \\
\text { No./pod }\end{array}$ & $\begin{array}{c}\text { Pod } \\
\text { weight }\end{array}$ & $\begin{array}{c}\text { Pod } \\
\text { length }\end{array}$ & $\begin{array}{c}\text { Pod } \\
\text { circum- } \\
\text { ference }\end{array}$ \\
\hline Pods/plant & $0.671 * *$ & $0.643 * *$ & 0.387 & $0.657 * *$ & $0.541 *$ & $0.730 * *$ & $0.703 * *$ & $0.700 * *$ & $0.833 * *$ & $0.806 * *$ \\
\hline Pod circumference $(\mathrm{cm})$ & $0.647 * *$ & $0.557 *$ & 0.361 & $0.488 *$ & $0.478 *$ & $0.964 * *$ & $0.899 * *$ & $0.948 * *$ & $0.968 * *$ & - \\
\hline Pod length $(\mathrm{cm})$ & $0.627 * *$ & $0.502 *$ & 0.253 & $0.515^{*}$ & $0.501 *$ & $0.946 * *$ & $0.896^{* *} *$ & $0.943 * *$ & - & \\
\hline Pod weight (g) & $0.627 * *$ & $0.496^{*}$ & 0.248 & 0.422 & $0.474 *$ & $0.971 * *$ & $0.929 * *$ & - & & \\
\hline Seed No./pod & $0.548 *$ & 0.417 & 0.122 & 0.366 & 0.428 & $0.958 * *$ & - & & & \\
\hline Seed weight (g) & $0.545^{*}$ & $0.463 *$ & 0.237 & 0.374 & 0.375 & - & & & & \\
\hline Plant height $(\mathrm{cm})$ & $0.879 * *$ & $0.721 * *$ & 0.447 & $0.891 * *$ & - & & & & & \\
\hline Stem girth $(\mathrm{cm})$ & $0.898 * *$ & $0.804 * *$ & $0.611 * *$ & - & & & & & & \\
\hline No of leaves & $0.647 * *$ & $0.861 * *$ & - & & & & & & & \\
\hline Leaf dry weight ( $g$ ) & $0.861 * *$ & - & & & & & & & & \\
\hline Stem dry weight $(\mathrm{g})$ & - & & & & & & & & & \\
\hline
\end{tabular}

$*$, ** - Correlation is significant at the 0.05 and 0.01 levels of probability, respectively.

\section{CONCLUSION}

In conclusion, this study has established existence of accessional differences in survival, growth and yield of Moringa oleifera in Nigeria as well as its response to manure application. It is evident that enough variability exists to warrant selection of accessions for genetic improvement or direct planting based on soil nutrient status or the farmer's competence.

\section{REFERENCES}

Adebayo A.G., Akintoye H.A., Olufolaji A.O., Aina O.O., Olatunji M.T. and Shokalu, A.O. (2011). Assessment of organic ammendments on vegetative development and nutrient uptake of Moringa oleifera Lam. in nursery. Asian J. of Plant Sci., 10, 74-79

Ani, J.U. and Baiyeri K.P. (2008). Impact of poultry manure and harvest season on juice quality of yellow passion fruit (Passiflora edulis var. Flavicarpa Deg.) in the sub-humid zone of Nigeria. Fruits, 63, 239-247

Baiyeri K.P. and Mbah B.N. (2006). Effect of soilless and soil based nursery media on seedling emergence, growth and response to waterstress of African breadfruit (Treculia africana Decne). African J. of Biotechnology, 5 (15), 1405-1410

Baiyeri K.P. and Tenkouano A. (2007). Manure placement influenced growth and dry matter yield of a plantain hybrid. African Crop Science Conference Proceedings, 8, 385-389

Beulah A.E. (2001). Growth and Development of Moringa (Moringa oleifera Lam.) cv. PKM 1 under Organic Systems of Agriculture. Ph.D. Thesis, Tamil Nadu Agricultural University Coimbatore, 3 pp.

Dauda N.S., Aliyu L. and Chiezey U.F. (2005). Effect of variety, seedling age and poultry manure on growth and yield of garden egg (Solanum gilol). Nigerian Academic Forum, 9, 88-95

Lamichhane D. and Thapa H.B. (2011). International provenance trial of Neem (Azadirachta indica) in the terai region of Nepal. Agroforestry Systems, 81, 37-43

Moyo B., Masika P.J., Hugo A. and Muchenje V. (2011). Nutritional characterization of Moringa (Moringa oleifera (Lam.). South Africa eco-type. African J. of Biotechnology, 10 (60), 12925-12933

Marcu M. (2006). The ideal food for the obese and malnourished. The Science Advisory Board Perspectives. Available online @ File:// E: $\backslash$ m 10.htm
Makker H.P.S. and Becker K. (1997). Nutrients and antinutrient factors in different morphological parts of the Moringa oleifera tree. J. Agric. Sc. (Cambridge), 128, 311-322

Ndukwe O.O., Baiyeri K.P., Muoneke C.O. and Tenkouano A. (2009). Impact of the organic and inorganic fertilizers on the postharvest fruit qualities of four Musa (AAB sub group) genotypes in sub humid zone of Nigeria. Global J. Agric. Sci., 8 (2), 185-194

Nouman W., Basra S.M.A., Siddiqut M.T., Asmeen A., Gull T. and Alcayde M.A.C. (2013). Potential of Moringa oleifera L. as livestock fodder crop: a review. Turkish J. Agric. Forestry, 37, 1211-1266

Obi I.U. (2002). Statistical Methods of Detecting Differences between Treatment Means and Research Methodology Issues in Laboratory and Field Experiments. AP Express Publisher Limited pp. 42

Olatunji O. and Oboh V.U. (2012). Growth and yield of okra and tomato as affected by pig dung and other manures, issue for economoic consideration in Benue State. Nigerian J. of Soil Science, 1, 103-107

Olatunji O., Ayuba S.A., Anjembe B.C. and Ojeniyi S.C. (2012). Effect of NPK and poultry manure on cowpea and soil nutrient composition. Nigerian J. of Soil Science, 22 (1), 108-113

Palada M.C. and Chang L.C. (2003). Suggested Cultural Practices for Moringa. International Co-operator's Guide AVRDC pub. 3-545 pp.

Price M.L. (2000). The Moringa tree - ECHO Technical Note, USA. Available online @ http://www.echonet.org/tropicalag/moringa3.htm

Price M.L. (2007). The Moringa Tree. ECHO technical 1 note. Revised edition. 11-12 pp.

Rajakrishanamoorthy V.S., Santhanabosu V.K., Duraisamy R. and Rakagopal A. (1994). Drip irrigation in annual Moringa: study of mineral nutrient value of green Madras Agric. J. Sci., 4, 317-318

Ramachandran C., Peter K.V. and Gopalakrishnan P.K. (1980). Drumstick (Moringa oleifera); A multipurpose Indian vegetable. Econ. Bot., 34, 276-283

Stevens C.G. (2014). Agronomic Evaluation and Biochemical Characterization of Twenty Accessions of Moringa oleifera Lam (Family Moringaceae) in Nsukka Agroecology. PhD Thesis, University of Nigeria, Nsukka, Nigeria. 240 pp.

Sunassee S. (2001). Use of poultry litter for vegetable production. AMAS, 2001. Food and Agricultural Research Council, Reduit, Mauritius, 259-263

Thompson L.M. and Troeh F.R. (1978). Soils and Soil Fertility, $4^{\text {th }}$ ed. MacGraw Hill Publication in Times, USA. Trust, Rothamsted Experimental Station 